\title{
Background, Current Scenario and Future Challenges of the Indian Silk Industry
}

\author{
Rubia Bukhari ${ }^{1 *}$ and Himpreet Kour $^{2}$ \\ ${ }^{1}$ Sher-e-Kashmir University of Agricultural Sciences \& Technology of Jammu, Main Campus \\ Chatha, Jammu, Jammu \& Kashmir - 180009, India \\ ${ }^{2}$ Department of Animal Husbandry Jammu \& Kashmir 180001, India \\ *Corresponding author
}

\begin{abstract}
A B S T R A C T
India is the second largest producer of silk and also the largest consumer of silk in the world having a strong tradition bound domestic market and it has the distinction of

Keywords

Indian silk industry, Mulberry, Silk fabric, Silk trade, Market share, Annual report

\section{Article Info}

Accepted: 20 April 2019 Available Online: 10 May 2019 producing all the four varieties of silk viz. Mulberry, Eri, Tasar and Muga. In India, due to favorable climatic conditions, mulberry is cultivated mainly in five states, viz., Karnataka, Andhra Pradesh, Tamil Nadu, West Bengal and Jammu \& Kashmir. These five states collectively account for $97 \%$ of the total area under mulberry cultivation and $95 \%$ of raw silk production in the country. The present global scenario clearly indicates enormous opportunities for the Indian Silk Industry. In 2016-17 the mulberry Silk Production Statistics estimated the world silk production to be 192,692 metric tonnes. China's contribution to world silk production is $80 \%(158,400$ metric tonnes), and the share of Indian silk production is 30,348 metric tons $(13 \%)$. China and India together account for 93\% of world silk production. According to the Annual Report of the Central Silk Board (CSB) for the year 2016-2017 the silk scenario of India Domestic demand 36,000 metric tonnes, Own production 30,348 metric tonnes, Gap in production 6000 metric tonnes, Raw silk imports 3795 metric tonnes, Silk fabric imports 3000 metric tonnes, Silk exports (worth Rs.) 2093.42 cr, Sericulture villages 52,360, Sericulture families 9, 47, 631, Employment (lakh persons) 85.10. The market share of Indian silk exports in the global silk trade is $4 \%$ to $5 \%$.
\end{abstract}

\section{Introduction}

Silk is the most elegant textile in the world with unparalleled grandeur, natural sheen, and inherent affinity for dyes, high absorbance, light weight, soft touch and high durability and known as the "Queen of Textiles" the world over. On the other hand, it stands for livelihood opportunity for millions owing to high employment oriented, low capital intensive and remunerative nature of its production. The very nature of this industry with its rural based on-farm and off-farm activities and enormous employment generation potential has attracted the attention of the planners and policy makers to recognize the industry among one of the most appropriate avenues for socio-economic 
development of a largely agrarian economy like India. Silk has been intermingled with the life and culture of the Indians. India has a rich and complex history in silk production and its silk trade dates back to 15 th century. Sericulture industry provides employment to approximately 8 million persons in rural and semi-urban areas in India. Of these, a sizeable number of workers belong to the economically weaker sections of society, including women. India's traditional and culture bound domestic market and an amazing diversity of silk garments that reflect geographic specificity has helped the country to achieve a leading position in silk industry. Asia is the main producer of silk in the world and produces over 95 per cent of the total global output. Though there are over 40 countries on the world map of silk, bulk of it is produced in China and India. India is the second largest producer of silk with 18475 MT (2006-07) and also the largest consumer of silk in the world. It has a strong tradition and culture bound domestic market of silk. In India, mulberry silk is produced mainly in the states of Karnataka, Andhra Pradesh, Tamil Nadu, Jammu \& Kashmir and West Bengal, while the non-mulberry silks are produced in Jharkhand, Chattisgarh, Orissa and northeastern states. About sixty lakh persons are engaged in various sericulture activities in the country. It is estimated that sericulture can generate employment of 11 man days per $\mathrm{kg}$ of raw silk production (in on-farm and offfarm activities) throughout the year. This potential is par-excellence and no other industry generates this kind of employment, especially in rural areas, hence, sericulture is used as a tool for rural reconstruction. Sericulture also provides vibrancy to village economies where about 57 per cent of the gross value of silk fabrics flows back to the cocoon growers thus; large chunk of income goes back to the villages from the cities (Table 7).

\section{Emerging scenario}

The Indian silk industry is passing through a crucial phase of reorientation and adjustment necessitated by the market forces. Therefore, at this juncture, it will be interesting to examine the extent to which different production and marketing system of the industry are capable of absorbing the changing market signals. It is also necessary to examine to what extent the output of the industry has been changing in terms of quantity and structure as a result of the changing demand patterns. This study addresses itself to some of these important issues relating to the post cocoon sector of the industry.

The silk industry has a distinctive position in India, that plays a significant role in textile industry and export. India is the 2nd largest producer of silk in the world with 23060 metric tonnes (MT) (2011-12) and also the largest consumer of silk in the world and contributes 15 per cent of the total world raw silk production. Geographically, Asia is the main producer of silk in the world and manufactures over 95 per cent of the total global output. Although there are over 40 countries on the world map of that produce silk, bulk of it is produced in China and India, followed by Japan, Brazil and Korea. China is the leading supplier of silk to the world with an annual production of 1,24,000 MT (201112), out of which the Mulberry raw silk production is $90,980 \mathrm{MT}$.

\section{Indian textile industry}

\section{A brief history}

India is well known for its textile goods from very ancient times. The traditional textile industry of India was virtually decayed during the colonial regime. However, the modern textile industry took its birth in India in the 
early nineteenth century when the first textile mill in the country was established at Fort Gloster near Calcutta in 1818. The cotton textile industry made its real beginning in Bombay, in 1850s. The first cotton textile mill of Bombay was established in 1854. From its inception, the industry passed through vicissitude of fortune till it reached its present status. As the industry grew up, the yarn trade with China fetched it good profit. The Indian market was not favourable initially, because of competition with Lancashire goods, but the natural advantages of humid climate, raw materials and an external market helped the growth of the industry considerably. During the later part of the last century, Japan became a rival to India in yarn trade with China and the Far Eastern Asia. During the First World War (1914-1918), Japan obtained better opportunities for marketing her yarn in China (Roy, 1996).

India was dependent considerably on the United Kingdom for the supply of machinery, caustic soda, bleaching powder, etc., for her cotton mills. The home market was not favourable to the industry because of competition with Lancashire fabrics which poured into India in large quantities. Production of yarn was more profitable than the production of cloth, since yarn could be marketed outside. Railway freight charges in India for transporting coal to the cotton mills were high as the coal had to be obtained from the Damodar Valley, the only important coal producing area in the country. It was, therefore, more profitable to import coal from South Africa by sea route for the cotton mills in India. This situation continued till water power was developed in Bombay and other areas in the early part of the 20th century.

The two world wars and the Swadeshi movement provided great stimulus to the Indian cotton textile industry. However, during the period 1922 to 1937 the industry was in doldrums and during this period a number of Bombay mills changed hands. The Second World War, during which textile import from Japan completely stopped, however, brought about an unprecedented growth in this industry. The number of mills increased from 178 with 4.05 lakh looms in 1901 to 249 mills with 13.35 lakh looms in 1921 and further to 396 mills with over 20 lakh looms in 1941. Thus by 1945 , there were 417 mills employing 5.10 lakh workers (Sastry, 1984).

\section{Growth of Textile Industry Since Independence}

After independence, the cotton textile industry made rapid strides under the Plans. Between 1951 and 1982, the total number of spindles doubled from 11 million to 22 million. It increased further to over 47 million by 2011-12. The Indian textile sector plays an exceptionally significant role in shaping the economy of India notably in terms of employment, foreign exchange earnings and share in value added. This sector is the second largest sector after agriculture. It has come of age and is gaining acknowledgment on the world platform with excellent textiles manufacturing base and availability of massive raw material. India being the second largest producer of cotton in the world, makes it self-sufficient, by providing a competitive edge to its competitors worldwide in terms of cost of raw materials. Along with abundant cotton production, India has the availability of highly skilled labour at very low prices (Texsummit, 2012).

\section{Domestic consumption}

The total Indian consumption of textiles and apparel is estimated at Rs. 2.85 lakh crores, out of which apparel retail contributes Rs. 2 lakh crores, technical textiles contributes Rs. 50 thousand crores and home textiles 
contributes Rs. 35 thousand crores. The market has grown at an annual growth rate of 13 per cent, since 2005-06. The domestic consumption has been propelled by several factors such as growing consumer prosperity and awareness, increasing availability of product variations, catching up with international trends, growth of organized retail, etc. On the basis of these factors, it is estimated that the Indian domestic consumption will become Rs. 5 lakh crores by 2016 growing at an overall annual rate of 12 per cent (Government of India, 2013).

\section{External trade}

Indian textile and clothing exports have come a long way in the last decade or so, tripling the exports value in this duration. Indian textile and apparel as an export category has excelled several large textile producers of past including Germany, Italy, USA, Turkey, etc. The reasons for excellent growth of textile and apparel exports from India is the country's strong raw material base, design and skill heritage, manufacturing capacities that are flexible for small orders, manpower cost competitiveness and government's incentive schemes for export promotion. India imports textile and apparel goods to the tune of Rs. 20 thousand crores, which comprises mainly of products like high end woolen / worsted fabrics, coated and performance fabrics, other technical textile and speciality products, fine cotton yarn dyed fabrics, premium and super premium garment categories, etc. The main reason for imports is the non-availability of the above said products. In recent years, even some inexpensive articles like raw silk, other fibres, basic fabrics and garments have also made inroads from suppliers like China (Gherzi Report, 2009).

With dismantling of the quota system in January 2005, investments in the textile sector have been raising and the export percentage too has increased drastically. Other government initiatives such as setting up of Special Economic Zones (SEZs) for textiles, and allowing 100 per cent foreign direct investment (FDI) in the textile sector have not only helped in creating opportunities for Indian entrepreneurs, but also for global investors. The structure of worldwide trade in textiles also marked a significant turn out after this period, as all the textile and clothing products can be traded globally without quota-restrictions. The elimination of quota restrictions on the export of textiles under the Agreement on Textile and Clothing (ATC) did facilitate India in escalating its market share of its major importers, but the growth rate remained much below expectations. The dismantling of the quota regime symbolizes both an opportunity and a threat. It can be an opportunity for the reason that markets will no longer be restricted and, also the domestic market will be exposed to competition. At domestic front, robust economic growth, rising demand, increasing consumerism, expanding organized retail and textile SEZs would provide healthy atmosphere for the growth of industry, whereas it also acts as a threat, as markets will no longer be assured by the quotas (Mayer et al., 2008).

\section{Structure of the Indian textile industry}

The textile sector in India is one of the world's largest industries. It is divided into three segments:

\section{Cotton Textiles}

2. Synthetic Textiles and

3. Others like Wool, Jute and Silk.

All segments have their own place but, even today, cotton textiles continue to dominate with 73 per cent share. The structure of the textile industry is extremely complex with the modern, sophisticated and highly mechanized 
mill sector on the one hand and hand spinning and hand weaving (handloom sector) on the other; in between falls the decentralised small scale power-loom sector. Unlike other major textile-producing countries, India's textile industry is comprised mostly of small-scale, nonintegrated spinning, weaving, finishing, and apparel-making enterprises. This unique industrial structure is primarily a legacy of government policies that have promoted labour-intensive, small-scale operations and discriminated against larger scale firms (Rangarajan, 2005).

\section{Silk Industry in India}

Silk is a lustrous, tough, elastic fibre produced by the larvae of silkworms; the term also covers the thread or cloth made from this fibre. The silk industry originated in China, as early as $2640 \mathrm{BC}$ according to tradition.

Towards the 3rd century AD, knowledge of the silkworm and its product reached Japan through Korea; it probably spread to India a little later. India is the largest consumer of silk in the world. Silk is a unique fabric which has gradually crept in everybody's home in some way or the other. The Indian silk industry is an integral part of the Indian textile industry and is among the oldest industries in India. It engages around 60 lakh workers and it involves small and marginal farmers. Indian silk industry is the second highest contribution of silk to the world production. Consistent market demand and remarkable approach has led to the widening of this industry (Bhushi and Pharsiyawar, 2004).

Silk is mainly produced in Pochampally, Kanchipuram, Dharmavaram, Mysore, etc., in South India and Banaras in the North for manufacturing garments and sarees. "Murshidabad silk", famous from historical times, is mainly produced in Malda and Murshidabad districts of West Bengal and woven with hand looms in Birbhum and Murshidabad districts. Another place famous for production of silk is Bhagalpur. The silk from Pochampally is particularly well known for its classic designs and enduring quality. The silk is traditionally hand-woven and hand-dyed and also usually has silver threads woven into the cloth (Sastry, 1984).

Among the four varieties of silk produced, in 2014-15, Mulberry accounts for $74.51 \%$ (21,390 MT), Tasar 8.5\% (2,434 MT), Eri $16.5 \%$ (4,726 MT) and Muga 0.55\% (158 MT) of the total raw silk production of 28708 MT. Production of raw silk in India during the year 2015-16 (April to August- 2015) has been 9,590 MT in which, mulberry and Vanya raw silk output amounts to 7,053 MT and 2,537 MT, respectively.

\section{Export and import performance of silk}

India exports considerable quantity of silk goods and the value of these silk goods is more than 15 per cent of the total raw silk production. India's export includes Dress Materials, Readymade Garments, Saris and Made-up articles for interior decoration. India's export has adequately progressed during the study period with both quantity and value of export showing high and significant growth.

This increased growth is also accompanied by higher volatility. India exports mainly to 10 countries viz., USA, UK, Hong Kong, German People Republic, Italy, France, Spain, Saudi Arabia, UAE and Singapore. The share of total Indian exports to these 10 countries constitutes 80 per cent (Table 1, 2 and 3).

\section{Raw silk imports}

The quantity and value of raw silk imported during XI Plan and during the first 4 years of XII Plan are given below: 


\section{Exports}

\section{Including silk yarn, fabrics \& made-ups, silk waste and silk RMG}

The Indian silk goods are being exported to the traditional major markets like the USA and European countries and small markets of Asia Region. The silk goods export earnings decreased over the years due to global recession. The export earnings during 201415 were Rs.2,829.88 crores. Export values of silk goods during XI Plan and during the first 4 years of XII Plan are given below: Table 6 shows an increase in the import of silk yarn and fabrics from the year 1999-00 to 2006-07. The import of silk yarn and fabrics was 1.62 in the year $1999-00$ and it rose to $23.59 \%$ in the year 2006-07 (Table 4 and 5).

\section{Silk mark expo}

In order to ensure that Silk Mark gains further credibility \& popularity, Silk Mark Expos are being organized exclusively for Silk Mark Authorized Users from across the country. The Expo is an ideal platform not only to popularize Silk Mark but also in bringing the manufacturers and the consumers under one platform for buying and selling of pure silk products. Substantial business for the participants is generated during this event. During the event massive awareness and publicity campaigns are carried out by the SMOI. During the year 2015-16 (till September-2015) seven Expos have been organised at Guwahati, Kochi, Puducherry, Thiruvanathapuram, Bhubaneshwar, Kolkata \& Ranchi against the annual target of 22 Expos.

\section{Brand promotion \& technology up- gradation}

During XII Plan, this new component is being implemented for the Brand Promotion of Indian Silk. This will provide tremendous impetus to the Indian Silk export promotion in international market. This can be in the form of advertisement and market promotion, participation in international show as 'Indian Silk Brand', establishment of laboratories at Kolkata, Sualkuchi for silk testing, etc.

Promotional programmes for Indian Silk at Sualkuchi, Uppada and Chanderi have been completed. - Exclusive Indian silk portal is under development. - Participated in ISC congress by showcasing the products developed at Sandur Kushala Kala Kendra, Bellary district by utilising the services of renowned visual artist from France Ms. Isabella Arcerio and the tribal women based in Sandur. - An exclusive e-commerce portal, www.silkmark.gocoop.com to promote the products of silk clusters has been set up. In the first phase, five clusters namely Varanasi, Bhagalpur, Uppada, Pochampalli and Sualkuchi have been covered. A fairly good response is being received for the portal from the consumers.

\section{Strengths of sericulture industry}

Sericulture has been identified as an occupation of low investments, employment creating and income generating. It has been found that sericulture is highly profitable as compared to many other crops. Sericulture involves simple technologies, easy to understand and adopt even by illiterate farmers and it gives returns in quick succession yielding income in every two or three months. Sericulture does not involve hard labour and rearing of silkworms is generally attended to by women and old people. Sericulture does not require sophisticated machinery and it involves use of simple appliances. Mulberry plants can be grown in any type of soil even in forest fringes, hill slopes and watershed areas. Sericulture ideally suits even in rain fed conditions because of its low cost of production and higher returns than any other 
crop. Mulberry plant withstands severe drought conditions and gives at least some income for sustenance while other agriculture crops wither away. Sericulture would be a more advantageous industry for improving the economy of retarded section of the society like scheduled caste and scheduled tribes. Non- mulberry sericulture is largely practiced by the tribals. Sericulture ideally suits small and marginal farmers.

In developing countries like India, agriculture and agro-based industries play a vital role in the improvement of rural economy. The limited availability of land, the limited cash returns, and agriculture being confined to one or two seasons in the year, have made villages to look for supporting rural industries, such as sericulture.

Agriculture and sericulture are adopted simultaneously by the agriculturists in regions where the ecological conditions are favourable. In India, over three million people are employed in various fields of sericulture. It is a cottage industry and provides ample work for the womenfolk in the rural areas in rearing silk worms, while the male members work in the fields. Recently the enforcing of new ideas by research institutions both in mulberry cultivation and silk-worm-handling among sericulturists, the industry is now practiced as a main profession and as a major cash crop of the country.

The strengths of silk industry can be summarized as follows:

Enormous production capacity

Efficient raw material manufacturing capacity

Large pool of skilled and cheap labor

Entrepreneurial skills

Enormous export potential

Large domestic market

Very low import content

Flexible silk manufacturing systems

The strength of this industry lies in its wide base, the sustaining market demand pull especially from the Indian handloom weaving sector, the infrastructure created by the national sericulture project and the research and training capabilities.

\section{Problems of Indian sericulture industry}

Though sericulture is ideally suited for improving the rural economy of the country, as it is practiced as a subsidiary industry to agriculture, it is hindered by various factors like imports of cheap and alternative textiles from other Asian neighbours, use of outdated manufacturing technology, primitive and unscientific "reeling" and "weaving" techniques, use of poor quality seeds, low production of bivoltine seeds, use of nongraded and diseased seeds, poor knowledge of farm disease amongst farmers, poor supply chain management, huge unorganized and decentralized sector, high production cost, recurring droughts and increased import of silk from China and accompanied with the following problems like:

\section{Price fluctuation}

2. Absence of proper market

3. Long distance to market

4. Lack of transport facilities

5. Absence of storage facilities

6. Poor information on market trend.

\section{Lack of finance}

In conclusion, today the Indian silk industry is already a major player in the global scenario and the growth prospects for the industry seem to be buoyant. Favorable climatic conditions and participation of large number of women in sericulture industry will lead to the development of silk industry to a greater height. 
Table.1 Performance of sericulture sector and achievement of silk industry during the plan period

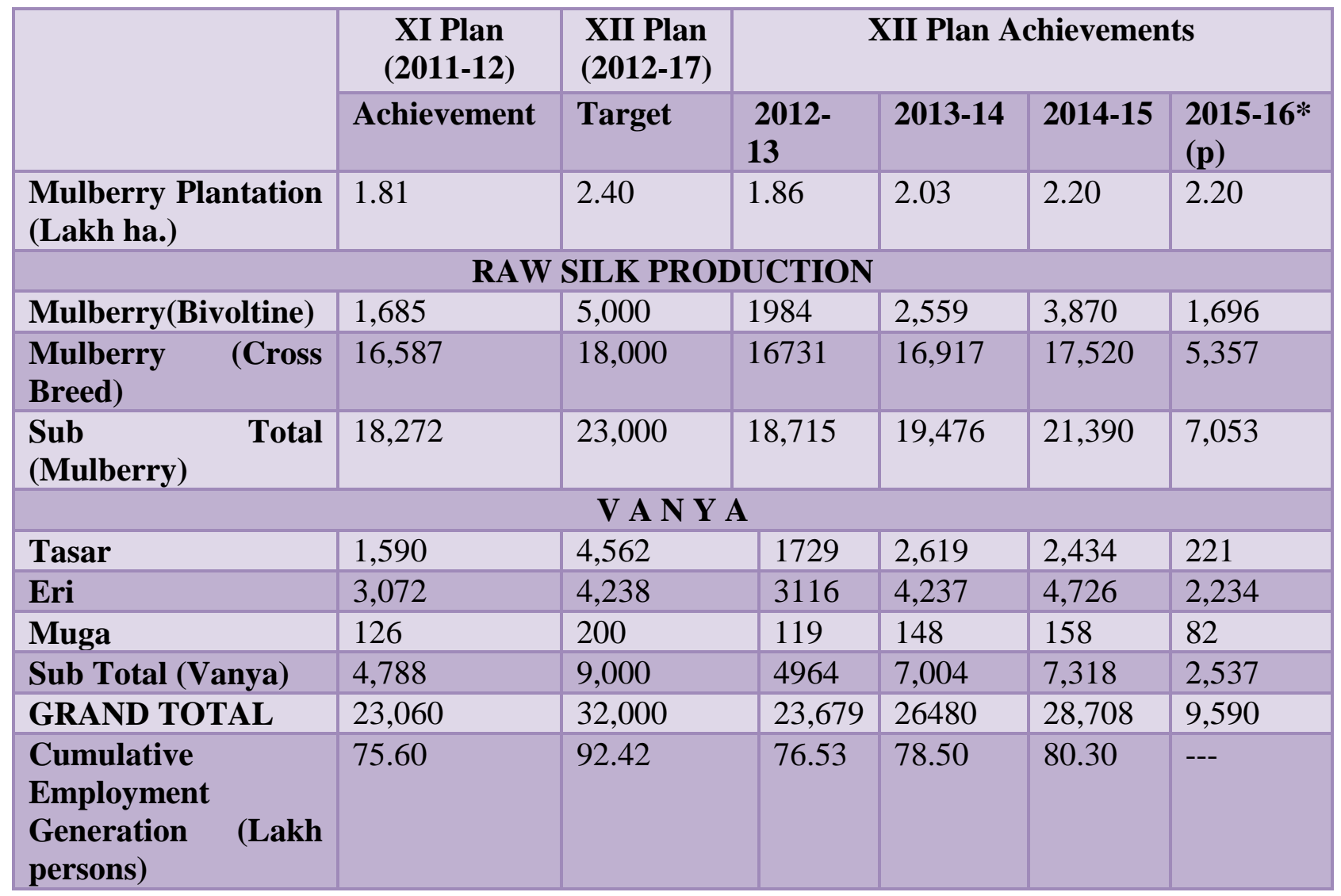

The State-wise production of Raw silk during 2012-13, 2013-14, 2014-15 \& 2015-16 (up to Aug-2015) are given in Annexure-I.

Table.2 Import of raw silk

\begin{tabular}{|l|l|l|}
\hline Year & Quantity in tonnes & Value (Rs.) \\
\hline $\mathbf{1 9 9 7 - 9 8}$ & 1876 & 2183.31 \\
\hline $\mathbf{1 9 9 8 - 9 9}$ & 1984 & 2593.64 \\
\hline $\mathbf{1 9 9 9 - 0 0}$ & 5018 & 4127.44 \\
\hline $\mathbf{2 0 0 0 - 0 1}$ & 4713 & 4732.61 \\
\hline $\mathbf{2 0 0 1 - 0 2}$ & 6808 & 6247.30 \\
\hline $\mathbf{2 0 0 2 - 0 3}$ & 9054 & 6471.50 \\
\hline $\mathbf{2 0 0 3 - 0 4}$ & 9258 & 6291.7 \\
\hline $\mathbf{2 0 0 4 - 0 5}$ & 7948 & 6374.3 \\
\hline $\mathbf{2 0 0 5 - 0 6}$ & 8383 & 7797.1 \\
\hline $\mathbf{2 0 0 6 - 0 7}$ & 5565 & 6733.7 \\
\hline $\mathbf{2 0 0 7 - 0 8}$ & 7922 & 7344.4 \\
\hline $\mathbf{2 0 0 8 - 0 9}$ & 8392 & 9030.6 \\
\hline $\mathbf{2 0 0 9 - 1 0}$ & 7338 & 9337.0 \\
\hline & Source: Ministry of Textiles in India \\
\hline
\end{tabular}


Table.3

\begin{tabular}{|l|c|c|}
\hline Year & Quantity (MT) & Value (Rs. in Crores) \\
\hline XI Plan 2011-12 & 5683 & 111.53 \\
\hline XII Plan2012-13 & 4959 & 1238.56 \\
\hline $\mathbf{2 0 1 3 - 1 4}$ & 3260 & 896.44 \\
\hline $\mathbf{2 0 1 4 - 1 5}$ & 3489 & 970.82 \\
\hline $\mathbf{2 0 1 5 - 1 6}$ (p) & 1443 & 412.47 \\
\hline
\end{tabular}

Source: DGCIS, Kolkata.

* Upto August-2015, (p)provisional

Table.4 Export of silk from India (Rs in Crore)

\begin{tabular}{|l|c|c|}
\hline Year & Exports $($ Rs) & Trend value $($ Rs) \\
\hline $\mathbf{1 9 9 7 - 9 8}$ & 1006.43 & 1422.85 \\
\hline $\mathbf{1 9 9 8 - 9 9}$ & 999.45 & 1593.74 \\
\hline $\mathbf{1 9 9 9 - 0 0}$ & 1755.55 & 1764.64 \\
\hline $\mathbf{2 0 0 0 - 0 1}$ & 2421.98 & 1935.53 \\
\hline $\mathbf{2 0 0 1 - 0 2}$ & 2359.56 & 2106.43 \\
\hline $\mathbf{2 0 0 2 - 0 3}$ & 2294.05 & 2277.32 \\
\hline $\mathbf{2 0 0 3 - 0 4}$ & 2779.19 & 2448.22 \\
\hline $\mathbf{2 0 0 4 - 0 5}$ & 2879.56 & 2619.11 \\
\hline $\mathbf{2 0 0 5 - 0 6}$ & 3194.20 & 2790.01 \\
\hline $\mathbf{2 0 0 6 - 0 7}$ & 3338.35 & 2960.90 \\
\hline $\mathbf{2 0 0 7 - 0 8}$ & 2727.87 & 3131.80 \\
\hline $\mathbf{2 0 0 8 - 0 9}$ & 3178.19 & 3302.69 \\
\hline $\mathbf{2 0 0 9 - 1 0}$ & 2892.44 & 3473.59 \\
\hline $\mathbf{2 0 1 0 - 1 1}$ & -------- & 3644.48 \\
\hline
\end{tabular}

Source: CSB, Bangalore

Table.5

\begin{tabular}{|l|l|l|l|l|l|}
\hline Items & $\begin{array}{l}\text { XI Plan (2011- } \\
\text { 12) }\end{array}$ & $\mathbf{2 0 1 2 - 1 3}$ & $\mathbf{2 0 1 3 - 1 4}$ & $\mathbf{2 0 1 4 - 1 5}(\mathbf{p})$ & $\mathbf{2 0 1 5 - 1 6 * ( p )}$ \\
\hline $\begin{array}{l}\text { Natural Silk } \\
\text { Yarn }\end{array}$ & 19.68 & 21.96 & 36.25 & 25.38 & 5.51 \\
\hline Silk Fabrics & 1497.97 & 1410.31 & 1455.63 & 1465.40 & 255.30 \\
\hline $\begin{array}{l}\text { Readymade } \\
\text { Garments }\end{array}$ & 765.83 & 787.15 & 874.00 & 1214.01 & 850.58 \\
\hline Silk Carpet & 20.08 & 21.14 & 15.71 & 15.97 & 6.52 \\
\hline Silk Waste & 49.77 & 62.97 & 99.30 & 109.12 & 38.19 \\
\hline Total & 2353.33 & $2,303.53$ & 2480.89 & 2829.88 & 1156.10 \\
\hline Source: FTSI \& MSFTI DGCIS, Kolkata & *upto August-2015, P: provisional &
\end{tabular}

Source: FTSI \& MSFTI, DGCIS, Kolkata

*upto August-2015, P: provisional

Note: Final Data is based on ITC (HS) codes details received from source data 
Table.6 Import of silk yarn and fabrics

\begin{tabular}{|l|c|c|}
\hline \multicolumn{2}{|c|}{} & Value in rs. Million \\
\hline Year & Silk yarn \& fabrics & \% of import \\
\hline $\mathbf{1 9 9 9 - 0 0}$ & 619.75 & 1.62 \\
\hline $\mathbf{2 0 0 0 - 0 1}$ & 910.21 & 2.38 \\
\hline $\mathbf{2 0 0 1 - 0 2}$ & 1729.94 & 4.53 \\
\hline $\mathbf{2 0 0 2 - 0 3}$ & 2930.4 & 7.68 \\
\hline $\mathbf{2 0 0 3 - 0 4}$ & 5298.9 & 13.88 \\
\hline $\mathbf{2 0 0 4 - 0 5}$ & 8030.6 & 21.04 \\
\hline $\mathbf{2 0 0 5 - 0 6}$ & 9645.8 & 25.27 \\
\hline $\mathbf{2 0 0 6 - 0 7}$ & 9004.9 & 23.59 \\
\hline
\end{tabular}

Source: Ministry of Textiles in India

Table No.6 shows an increase in the import of silk yarn and fabrics from the year 1999-00 to 2006-07. The import of silk yarn and fabrics was 1.62 in the year $1999-00$ and it rose to $23.59 \%$ in the year 2006-07

Table.7 State wise Raw Silk production during 2012-13 to 2015-16 ～(in MT)

\begin{tabular}{|c|c|c|c|c|c|}
\hline \multirow[t]{2}{*}{ S.No } & \multirow[t]{2}{*}{ State } & \multicolumn{4}{|c|}{ Achievement } \\
\hline & & 2012-13 & 2013-14 & 2014-15 & 2015-16 (P) (upto Aug 2015) \\
\hline 1 & Karnataka & 8219 & 8574 & 9645 & 3576 \\
\hline 2 & Andhra Pradesh & 6550 & 6912 & 6485 & 1558 \\
\hline 3 & Telangana & - & - & 101 & 27 \\
\hline 4 & Tamil Nadu & 1185 & 1120 & 1602 & 776 \\
\hline 5 & Kerala & 6 & 4 & 7 & 3 \\
\hline 6 & Maharashtra & 97 & 122 & 221 & 74 \\
\hline 7 & Uttar Pradesh & 157 & 188 & 236 & 36 \\
\hline 8 & Madhya Pradesh & 190 & 195 & 248 & $24 * *$ \\
\hline 9 & Chhattisgarh & 391 & 391 & 234 & 37 \\
\hline 10 & West Bengal & 2070 & 2079 & 2500 & 687 \\
\hline 11 & Bihar & 22 & 52 & 53 & $1.34 *$ \\
\hline 12 & Jharkhand & 1090 & 2003 & 1946 & $180 *$ \\
\hline 13 & Odisha & 104 & 53 & 98 & 1.74 \\
\hline 14 & Jammu \& Kashmir & 145 & 136 & 138 & 131 \\
\hline 15 & Himachal Pradesh & 23 & 25 & 30 & 25 \\
\hline 16 & Uttarakhand & 17 & 22 & 29 & 16 \\
\hline 17 & Haryana & 0.13 & 0.13 & 0.3 & 0.37 \\
\hline 18 & Punjab & 5 & 4 & 4 & 1.02 \\
\hline 19 & Assam \& Bodoland & 2068 & 2766 & 3222 & $1859 * *$ \\
\hline 20 & Ar.Pradesh & 22 & 15 & 12 & $8 *$ \\
\hline 21 & Manipur & 418 & 487 & 516 & $147 *$ \\
\hline 22 & Meghalaya & 517 & 644 & 656 & $155^{*}$ \\
\hline 23 & Mizoram & 40 & 44 & 50 & 30 \\
\hline 24 & Nagaland & 324 & 606 & 619 & $218^{*}$ \\
\hline 25 & Sikkim & 3 & 0.20 & 8 & $3 *$ \\
\hline 26 & Tripura & 15 & 40 & 48 & $15^{*}$ \\
\hline & Total & 23,679 & 26,480 & 28,708 & 9590 \\
\hline
\end{tabular}


Measures like the encouragement of additional technological and economic research in the various aspects of sericulture, standardization and quality control of silk and silk products, provision of quality seeds, imparting knowledge among the farmers regarding farm disease and rationalization of marketing and stabilization of prices of silk cocoons and raw silk, it could expand rapidly than ever before. Though, this sector has been identified as a sector of the Indian economy with strong potential to create jobs and able to contribute to foreign trade, it is not even nearer to the production of china. With Japanese technology and cooperation, Central Silk Board has recently been able to evolve and popularize Bivoltine silkworm races which can yield raw silk of international standards thereby increasing production. With these races, we can expect reforms in the marketing and processing of cocoons, India can hope to develop its sale of domestic raw silk beyond its own borders. In conclusion, it can be said that India can take up the challenge of production of high quality silk in required quantity to meet the domestic requirement as well as to earn valuable foreign exchange. The textile sector is also developed to support the agro system so that optimum value addition is possible.

\section{References}

A Review", paper presented at International Conference on Sericulture Challenges in 21st Century, 18-27 Sept, 2007, Vratza, Bulgaria.

Acharya J. 1993 Sericulture and development. Indian Publishers Distributors, New Delhi.

Agarwal, Sarita (1996) - "Division of Labour and Employment: Conditions with Surat Art Silk Industry", The India Journal of Labour Economics, Vol 39, No.2, 1996.

Aiyaswamy PK. 1980 Income and employment potentials of sericulture in
Coimbatore district. Abstract, Processing symposium and seminar on sericulture, Tamil Nadu Agricultural University, 239-243.

Alkire Sabina, R Meinzen-Dick, A. Peterman, A.R. Quisumbing, G Seymour and A.Vaz (2012): "The Women Empowerment in Agricultural Index", International Food Policy Research Institute- Discussion Paper-1240, Dec 2012.

Ananta Raman and Phaniraj (2007) "Training, Feasibility of Human Resource Development for Sericulture in India -

Anitha, R. (2011) Management Studies International Journal of Multidisciplinary, 1(3): 22498834.

Annual Report of Sericulture Central silk Board, Govt. of India, Bangalore, 201617, 1-28.

Benchamin KV, Jolly MS. 1987 Employment and income generation in the rural areas through sericulture. Indian Silk, 26(2):913.

Best, M. L. and Maier, S. G. 2007 Gender, culture and ICT use in rural South India. Gender Technology and Development, 11:137-155.

Bhatta, R. and Rao, K. A. 2003 Women's livelihood in fisheries in coastal Karnataka, India. Indian Journal of Gender Studies. 10:261-278.

Bisen, D. K., Bisen, P. K., Sarangi, A. K. 2005 Economics of cocoon production on mulberry in Balaghat district of Madhya Pradesh. JNKVV Research Journal, 38(2):41-44.

CARE (2009) - "Bringing Financial Sector to Africa's Poor", Microfinance in AfricaState of the Sector Report, CARE.

Chand, R. (2004) Emphasizing on modernization, The Hindu Survey of Indian Agriculture, Chennai. 77-80.

Chandrasekar, R. Income and employment generation in sericulture $\mathrm{Vis}$ a Vis 
alternative crops in Hosur taluk of Dharmapuri district. M.Sc Thesis, University of Agricultural Sciences, Bangalore, 1985.

Charsely (1976 - "Finance and Raw Silk Industry", Economic \& Political Weekly, Vol XI. No.48, Nov. 27, 1976

Charsely S R (1982)- Culture and Sericulture, Academic Press, New York.

Chowdhury SN. Muberry silk industry. Published by Dibrugarh Assam, 1984, 27(1).

Commissions of Sericulture (2007)- Potential for Participation of Women in Sericulture Sector, Keynote address presented on National Conference on Women in Sericulture, Mysore, 16-17th March 2007.

Creevey LE. India - the sericulture project.Changing Women's lives and work.An analysis of the impacts of eight micro enterprise Projects, 1996, 110-131.

Cuddy and Delle, V. (1978) Measuring the instability of time series data, Oxford Bulletin of Economics and Statistics.

Dandin SB. Involvement of women in Sericulture. Survey Report, Karnataka State Sericutural Research and Development Institute, Bangalore, 1994.

Department of Sericulture, Chhattisgarh, Detail report. Sonakhan Bhawan, Raipur, 2017.

Devaki Jain (2007) - 'To Be or Not to Be'The Location of Women in Public Policy, Economic \&Political Weekly, Feb 24, 2007

Devasurappa (2004) "Silk Industry in Karnataka" Tamilnadu Agriculture University, Coimbatore.

Dewangan SK, et al., Breaking of poverty through sericulture- among the tribe- A Socio-Economic study of Dharamjaigarh block of Raigarh district, C.G, India. Research journal of
Recent Sciences.2012; 1:371-374.

Dewangan SK, et al., Socio economic upliftment of Tribal through Tasar sericulture- a study of Tamnar block of Raigarh district, C.G, India. World Academy of Science, Engineering and Technology. 2011; (72):481-492.

DHDR, Malda (2007) - "Gender Differentials \& Gender Issues”, Ch 6 HDRCC, Development \& Planning Department, Government of West Bengal.

Eswarappa Kassa (2005) - "Sericulture and Community Development in the context of Globalization: An Empirical Evidence of a Village", presented in a National Seminar at Osmania University, on 17-18th February, 2005

G.S. Rani (2006) - Women in Sericulture, Discovery Publishing House, New Delhi

Ganapathi Rao Ratnala, Mallikarjuna B, Datta RK. Human labour employment in sericulture - an empirical study in Andhra Pradesh. Indian J Seric. 1995; 34(2):9092.

Ganga G, Chetty J. Sulochana an Introduction to Sericulture. IBH Publishing Company, 1991.

Gangopadhyay D. Sericulture Industry in India: A review, 2009. www.nistads.res.in/indiasnt2008.

Garda Ghista(online): "Women at Mercy of Globalization", www.proutworld.org/index.php

Gayathri Devi KG. Karnataka: A status report on women in sericulture. Indian Silk, 1994; 31(11):31-38.

Ghosh Jayati (2004) - Informalisation and Women's Workforce Participation: A Consideration in Recent Trends in Asia, UNRISD

Gita Sen and Chiranjib Sen (1985) - Women's Domestic Work and Economic Activity - Results from National Sample Survey, Economic and Political Weekly, Vol XX, No. 17, April 27, 1985 Hanumappa 
Global Silk Scenario (2001) Proceedings of International Congress on Tropical Sericultural Practices, Bangalor, India.121-130.

Goyal A. Women making choices: Masked but aware? Ind. Jou of Gender Studies.2007; 14:409-437.

Gu, G. D. (1999) Study on the output of cocoon and raw silk and distribution of Sericultural areas in the world. Sericulture Science, 25, 105-114.

Gulati, A. (2002) Indian agriculture in a globalizing world. American Journal of Agricultural Economics, 84 (3): 754761.

H G (1986)- Sericulture for Rural Development, Himalaya Publishing House, Mumbai

Hanumappa H G (1993)- Sericulture Society and Economy, Himalaya Publishing House, Mumbai

Hanumappa HG. Sericulture for rural development. Himalaya Publishing House, 1986, 1-57.

Hanumappa, H.G., and S. Erappa (1986): "Economic Issues in Sericulture: Study of Karnataka", Economic and Political Weekly, Vol XX (31) pp 1322-1324.27

He, J. H. (2010) Silk is China and China is Silk. A response to Good et al., (2009). Achaeametry, University of Oxford, 1475-4754.

Hegde N.G. (2005) - Women empowerment for Promoting Sustainable Livelihoods in Rural India, Empowerpoor.org, Vol 2, Issue 2, May 2005

http://agropedia.iitk.ac.in/content/sericultureindustry.

http://texmin.nic.in/Silk\%20Industry.pdf

http://www.deccanherald.com/content/45585/ reelers-complain-toxic-silk.html http://www.indiankanoon.org/doc/1809930/

http://www.tnsericulture.gov.in/prototype2/im ages/template1_01.gif

http://www.indiansilk.kar.nic.in/.

Jayaram H, Mallikarjuna B, Lakshmanan S,
Ganapathi Rao R, Geetha Devi RG. Labour employment under different mulberry farm holdings: A comparative study. Indian J Seric. 1998; 37(1):52-56. Jayaram H., V. Mallikarjun, S. Lakshman, R. Ganapathi Rao and R.G. Geetha Devi (1998): Labour Employment Under Different Mulberry Farm Holdings, Indian Journal of Sericulture, Vol 37 (01), p52-56.

Jhavala \& Sinha (2002)- "Liberalization and Women Worker", Economic and Political Weekly, May 25, 2002

Jolly MS. Sericulture and its economics. In: Appropriate Sericulture Techniques, 1987, 1-16. Kalappa A, Vijaya Kumar P, Vidya Bharathi Research Journal of Social Science. 1988; 9: 20-32.

K.C. Harrison, (1998) "Silk Stalkings: More Women Write of Murder", Reference Reviews, 12(7): 26 - 27

Kadekodi, Kanbur \& Rao (2007)-“ Governance and the Karnataka Model of Development", Eonomic \& Political Weekly, Feb 24, 2007

Kannan VA. Women in silk industry, Indian Silk. 1987; 26(11):14-17.

Kasi, Eswarappa. Development and Change Due to Sericulture: A Village Study in Chittoor District. Hyderabad: University of Hyderabad, 2000.

Krisnaswami, S., Madhava, R. S. K., Suryanarayan and Sundaramurthy, T. S. (1972) Sericulture Manual 3-silk reeling. FAO. Agricultural Services Bulleting 15:122.

Kumaresan P, Vijaya Prakash NB. Economics of sericulture vis-a-vis competing crops in Erode district of Tamil Nadu. Indian J Seric. 2001; 40(2):142-146.

Lakhshmanan S. and Geetha Devi R.G. (2007)- "Tamil Nadu: Employment Opportunities in Sericulture", Indian Silk, Nov, 2007

Lakshman, S., B. Mallikarjuna, R. Ganapthi Rao, H. Jayaram and R.G. Geetha Devi 
(1999): "An Empirical Investigation on Labour Productivity in Mulberry Sericulture", Indian Journal of Sericulture, Vol 38 (1) p48-52.

Lakshmanan S, Geetha Devi RG. Employment generation in dry farming sericulture in Karnataka: An empirical study. Man Power J. 2007b; 42(1):181198.

Lakshmanan S, Jayaram H, Ganapathi Rao R, Mallikarjuna B, Geetha Devi RG. Manpower utilization in mulberry sericulture: An empirical analysis. Man power. 1998b; 33(4):49-63.

Lakshmi Prasad V. A comparative economic analysis of cocoon production between mulberry growing and non-growing farmers in Kolar district.University of Agricultural Sciences, Bangalore, 2005.

Leela Gulati (1975) - "Female Work Participation: A Study of Inter State Difference", Economic and Political Weekly, Jan. 17, 1975.

Lutz, E. and Scandizzo, P. (1980) Price distortions in developing countries: A bias against agriculture, European Review of Agricultural Economics, 7(1): 5-27.

Maithreyi Krishnaraj (1990)- “Women's Work in Indian Census: Beginnings of Change", Economic and Political Weekly, Dec1-8, 1990

Mamatha Girish (2004) "Sericulture-based optimum farming system models for small farmers"productivity.307 -311.

Margaret, M. (2006) "Trying to make a silk purse from a sow's ear? A comment on the government's prostitution strategy", Safer Communities, 5(2): 4 - 13

Miao, Y. (2002) Conservation Status of mulberry genetic resources in China. Expert Consultation of Global Exchange of Sericulture germplasm. Satellite Meeting of xix ISC Congress, September, $21^{\text {st }}$ to $25^{\text {th }}$

Mukherjee Mukul (2004): “A Situational
Analysis of Women \& Girl in West Bengal", National Commission for Women, New Delhi

Murugesh, M. (2007) 'Silk and its nonconventional uses'. Kisan world, 21 24.

Murugesh, M. and Subramanian. (2006) "Silk Production In India" Kisan World, 2324.

Murugesh, M. and Subramanian .(2007) 'Ericulture - A new silk prospect',21 25.

Nagaraj N, Chandrakanth MG, Murthy SRS 1986b. The economics of sericulture in Karnataka. Indian Silk. 25(4):13-19.

Naresh NT, Narayana Gowda K. 2000 Adoption behaviour of trained sericulture farm women. Journal of Extension. Edison. 11(2):2731-2737.

Nassig WA, Lempe REJ, Kger S. The saturniidae of Sumatra. Heterocera Sumatrana. 1996; 10:3-10.

Nayyar Rohini (1987) - "Female Participation Rates in Rural India", Economic and Political Weekly, December 19, 1987, pp.2207-2216

Padma Tripathi, Comparative economics of silk growers on the basis of land holding. Indian Silk. 2000; 39(8):5-6.

Pandey A.P. and Shivesh (2007) - "Wage and Income Differential on the Basis of Gender in Indian Agriculture", (unpublished) Munich Personal Repec Archive (http://mpra.ub.unimuenchen.de/6088/1/MPRA_paper_608 8.pdf)

Periaswamy (1977) - "Problems and Prospects of Sericulture", Indian Silk, Vol VXI, No.6, October.

Pillai MP, Shanta N. ICT and employment promotion among poor women: How can we make it happen? Some reflections on Kerala's experience. Indian Journal of Gender Studies.2011; 18:51-76.

Pushpa J, Netaji SR. 1999Impact on income 
and employment of farmers in various integrated farming system. Journal of Extension Edison, 10(4):2628-2630.

Qadri SMH, Dandin SB. Bivoltine sericulture promotion|: The Tamil Nadu way. Indian Silk. 2006; 45(2):11-15.

Radha Krishna, Sekharappa and Manibashetty (2000): "Silk and Milk - An Economic Package for Rural Upliftment", Indian Silk, Sept 2000, pp.11-12

Raja Purohit (1985) - "Tasar Silk Programme for Women": A Techno Economic Evaluation, Bihar, 1985

Rajapurohit AR, Govindaraju KV. Income and Employment in Sericulture. Shiny Publication, Bangalore.

Rajesh B. A study on economics of rainfed sericulture in recurrent drought prone areas of Karnataka. M.Sc. Thesis, University of Agricultural Sciences, Bangalore, 1995.

Ram, K. (2007) "Economics of silk Industry in India" Tamilnadu Agriculture University.

Ramakrishna, G., Sivarama, K. V. and Sukar, A. (2002) Impact of globalization on growth, poverty and income inequality: A study of Ethiopia and India, Asian Economic Review, 45 (2): 326-341.

Ramesha and Sinha (2009): "Rural Women Empowerment Motivates Me", Indian Silk. 48(5), Sept 2009.

Ravindra, K. (2008) 'History of silk and its prospects in Jharkhand', Kurukshetra, Pp. $41-45$.

Reddy and Kamalamma (2000) - "Problems of Women in Sericulture - A Case Study in Tamil Nadu", Indian Silk, Sept 2000, pp. 19-22

Reddy (1994): Women - "The Strength of Sericulture", Indian Silk, Jan 1994, pp. 3-7, Report of the Working Group on Empowerment for XI-th Plan (2006): Ministry of Women \& Child Development, Government of India, http://wcd.nic.in/wgfinalreport.pdf.
Reddy, R.M., 2010c. Silkworm food plants apply dimension under Indian condition - time for utility optimization and value addition. Sericologia. 1981; 50(1):0117.

Report of The working group on Textiles \& jute industry for the eleventh five year plan (2007-2012) Government of India Ministry of textiles http://indiansilk.kar.nic.in/rti/CO/World RawSilkProduction.pdf http://www.scribd.com/doc/55511204/4 /WORLD-RAW-SILK-PRODUCTION

Roy Chandan and Jiten Barman (2012): "Child Labour \& Inclusive Education in Backward Districts of India", International Journal of Education, Vol. 4, No.4, p 311-327.

Roy Chandan, Sanchari Roy Mukherjee and Santanu Ghosh (2012): Sericulture as an Employment Generating Household Industry in West Bengal: A Study on its Current Problems and Prospects, Artha Beekshan, Vol 21, No.3.

Sahara Razvi (2001) - "Globalization, Employment and Women's Empowerment", paper presented at Geneva on UN Division for Advancement of Women, Expert Group Meeting (26-29 Nov, 2001)

Sandhya Rani, G (1992): "The Triumph of Sericulture in Andhra Pradesh," Indian Silk, Vol XXX, No.9, Jan. 199228

Saraswathi, J.M. and P.R. Sumangala (2001): Participation of Farm Women in Sericulture Enterprise, Indian Journal of Sericulture, Vol 40(1), pp 86-91.

Savithri G, Sujathamma P. Participation of women in sericulture. Bulletin of Indian Academy of Sericulture. 2003; 7(2):102-106.

Sen Amartya (1999): Development as Freedom, Oxford University Press, Oxford Shetty \& Dileep Kumar (2009) "Health Insurance for Women in Sericulture", Indian Silk, Vol 47, No 2, 
April 2009.

Shrivastav PK, et al., Sericulture activities provide a perfect choice for the women. Sericulture and seribiodiversity, 2005.

Siddagangamma.Division of labour in mulberry cultivation and silkworm rearing. National Conference on New Strategies in Research and development of Sericulture - Indian Perspective, March 9-10, Department of Sericulture, Jnanabharathi Campus, Bangalore, 2006, 128.

Suryanarayana N, Kumar R, Gargi. Monograph on Indian Tropical Tasar silkworm food plants Central Tasar Research and Training Institute C S.B, Ranchi, India, 2005, 1-9.

Swaminathan MS. The future of our sericulture industries. Indian Silk. 1988; 26(12):1-2.

Swaminathan Padmini (2009) - "Outside the Realm of Protective Labour Legislation: Saga of Unpaid Labour in India," Economic \& Political Weekly, Oct 31, 2009 Vol XLIV, No. 44

texmin.nic.in/.../Fibre_Policy_Sub_\%20Grou

ps_Report_dir_mg
Thomas BK, Muradian R, de Groot G, de Ruijter A. Resilient and resourceful? A case study on how the poor cope in Kerala, India. Jou. Of Asian and African Stud. 2010; 45:29-45.

Ullal,S. R. and Narasimhanna, M.N.( 1987 ). Hand Book of Practical Sericulture. Central Silk Board Bangalore, India. 166.

Usha Rani (2007)- "Employment Generation to Women in Drought Prone Areas: A Study with Reference to the Development of Sericulture in Anantpur District of Andhra Pradesh", Journal of Social Science 14(3), 249-255.

Vijayanthi KN. Women's empowerment through self-help groups: A participatory approach. Indian Journal of Gender Studies.2002; 9:263-274.

\section{WEBSITES}

www.amazon.com/Sericulture-India-PVenkata-Narasaiah/dp/8170245087 $214 \mathrm{k}$

www.krishiworld.com/html/seri_ind1.html $17 \mathrm{k}$.

www.roionline.org/uploads/ROI_2010_Silk

\section{How to cite this article:}

Rubia Bukhari and Himpreet Kour. 2019. Background, Current Scenario and Future Challenges of the Indian Silk Industry. Int.J.Curr.Microbiol.App.Sci. 8(05): 2448-2463.

doi: https://doi.org/10.20546/ijcmas.2019.805.289 